\title{
EVOLUTION OF HALIDES FROM HALOGENATED PLASTICS EXPOSED TO GAMMA RADIATION
}

AUTHORS:

J. Byrne

W. L. Mann

MASSACHUSETTS INSTITUTE OF TECHNOLOGY Engineering Practice School

Prepared From Work Performed Under Subcontract 70 With The CARBIDE AND CARBON CHEMICALS COMPANY A Division of Union Carbide and Carbon Corporation TE OF TEC Oak Ridge, Tennessee 


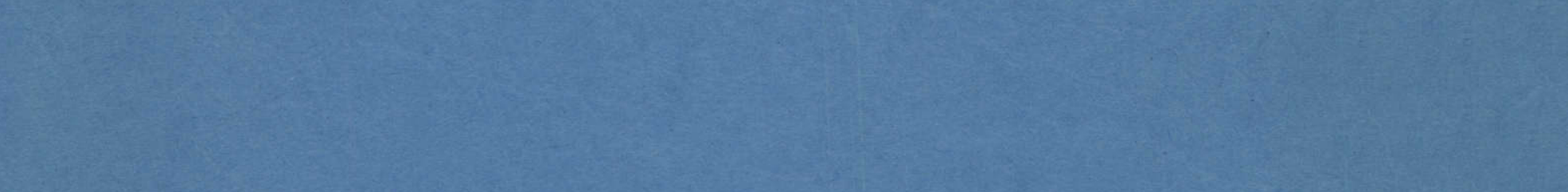

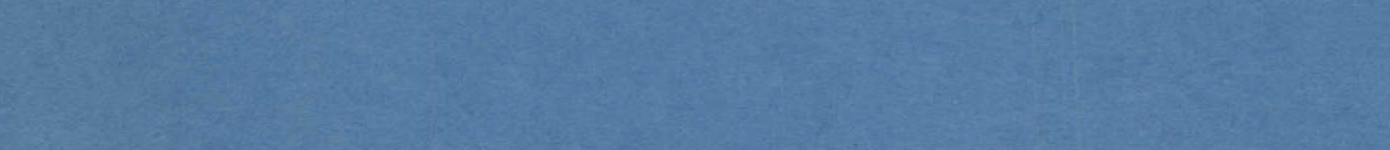

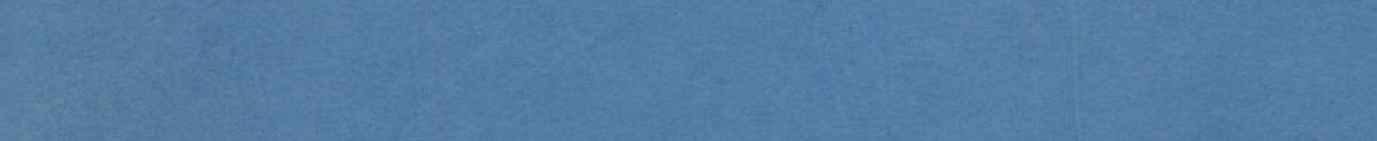

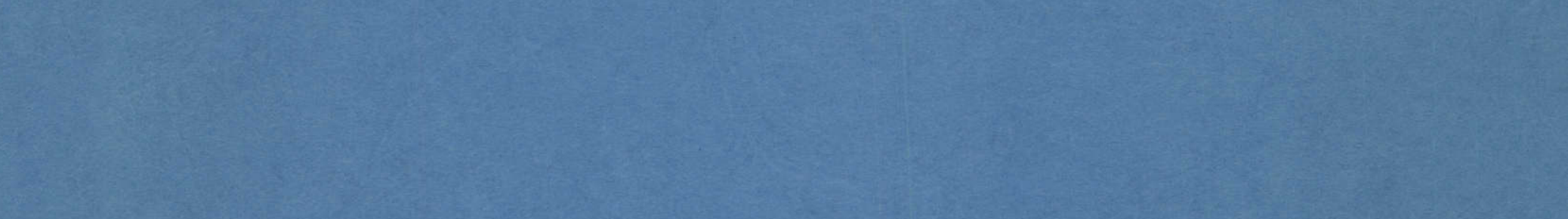

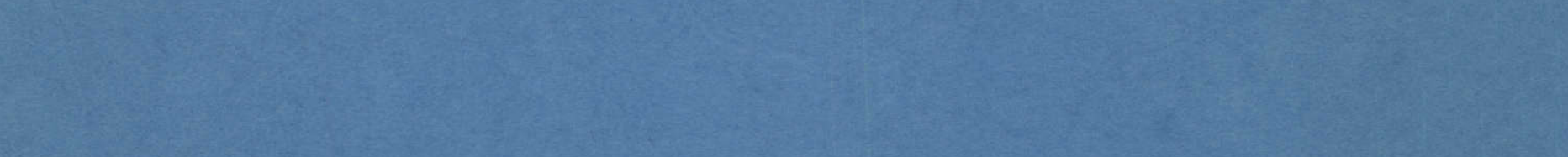

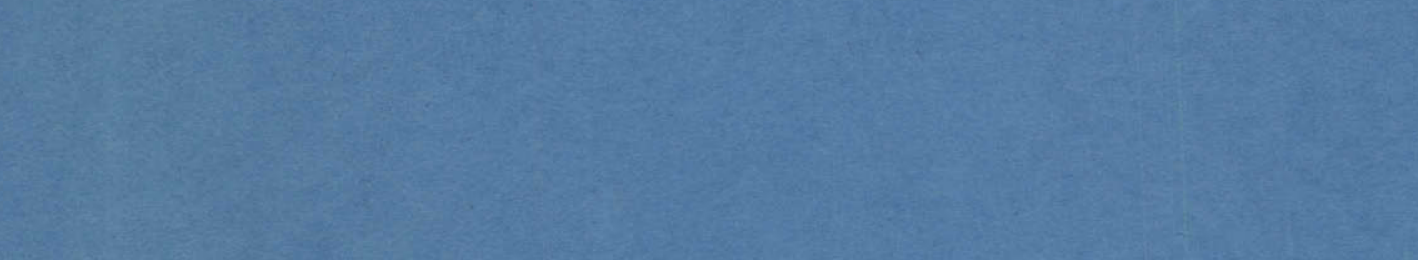

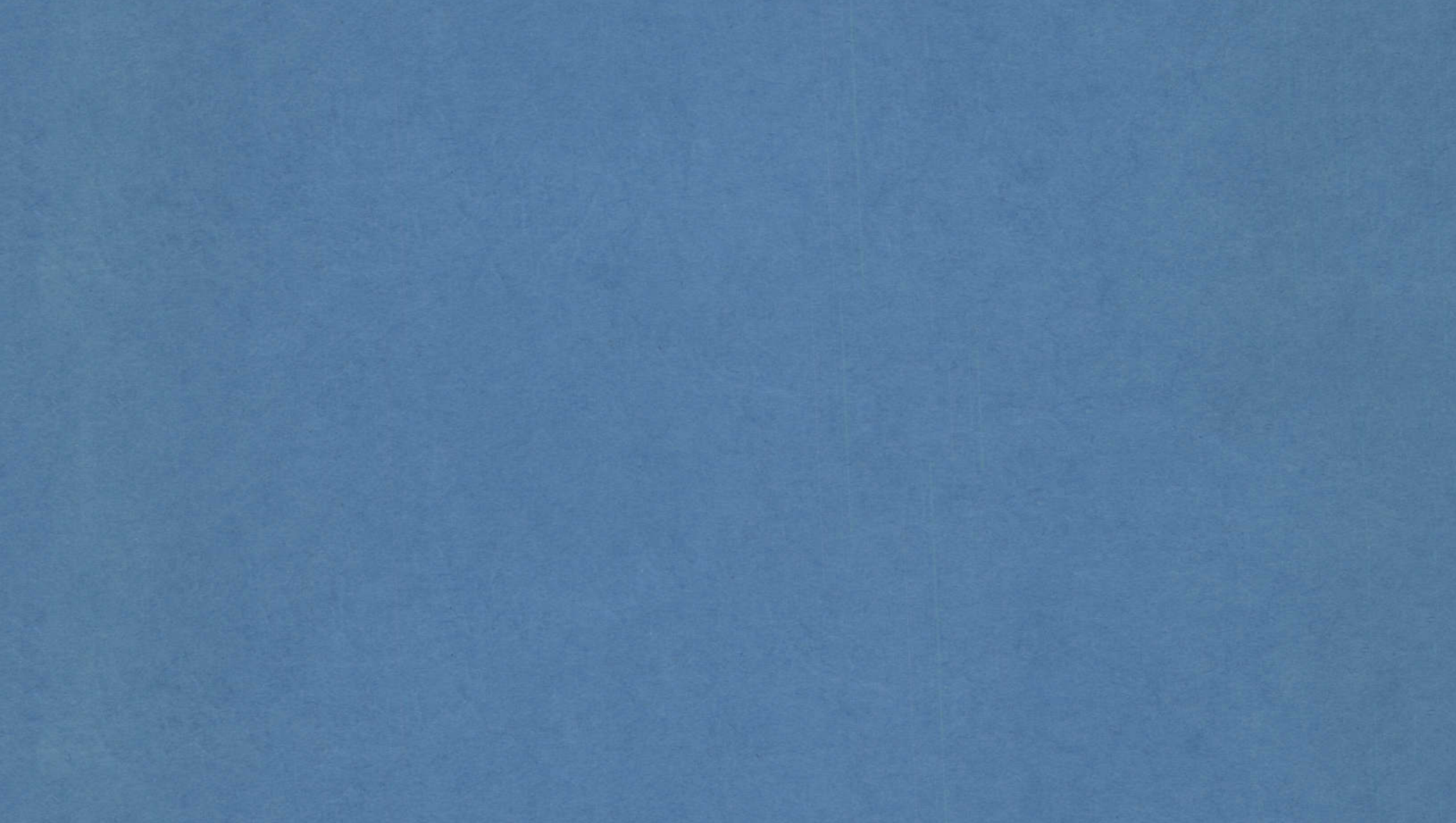

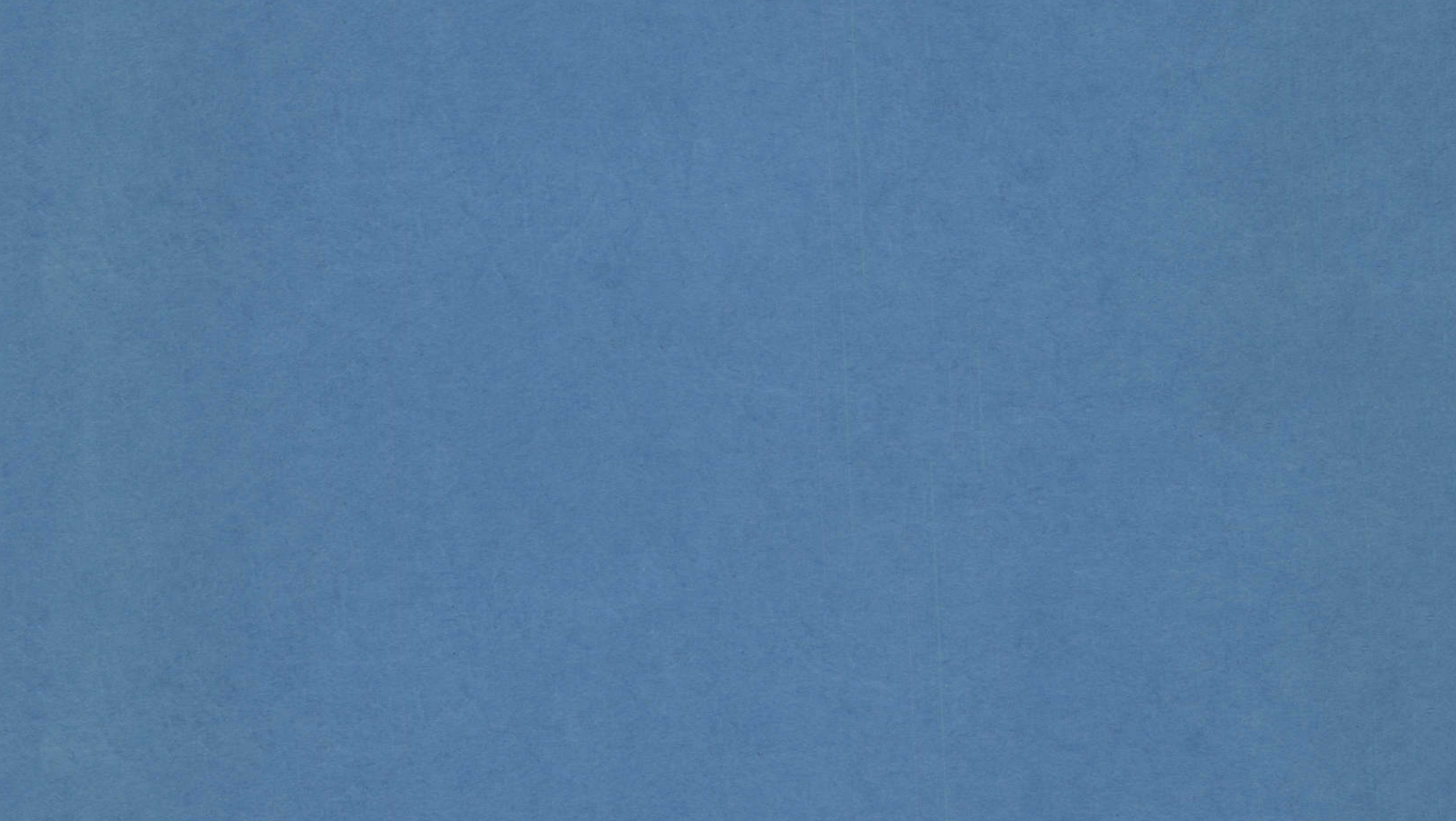

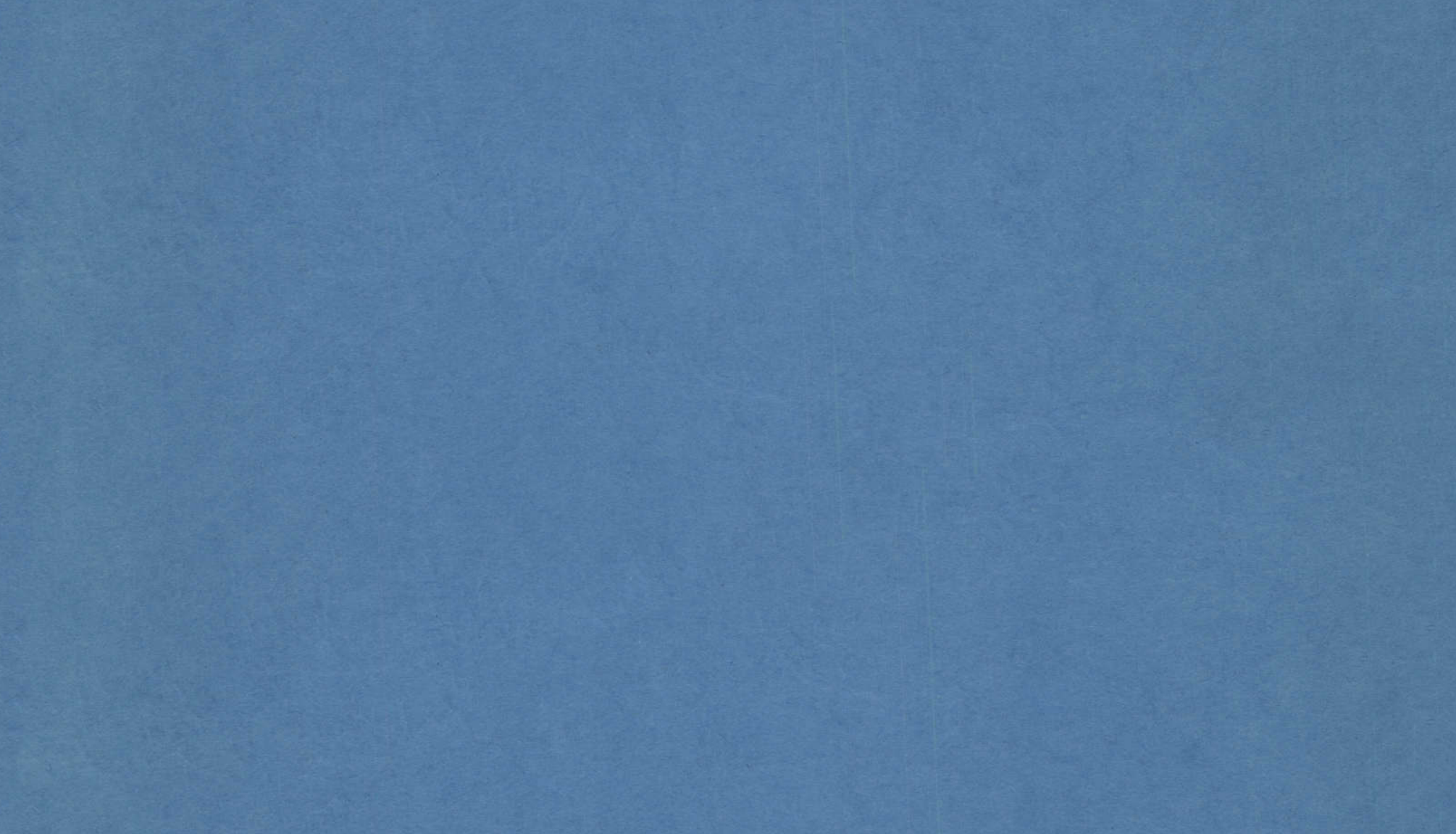

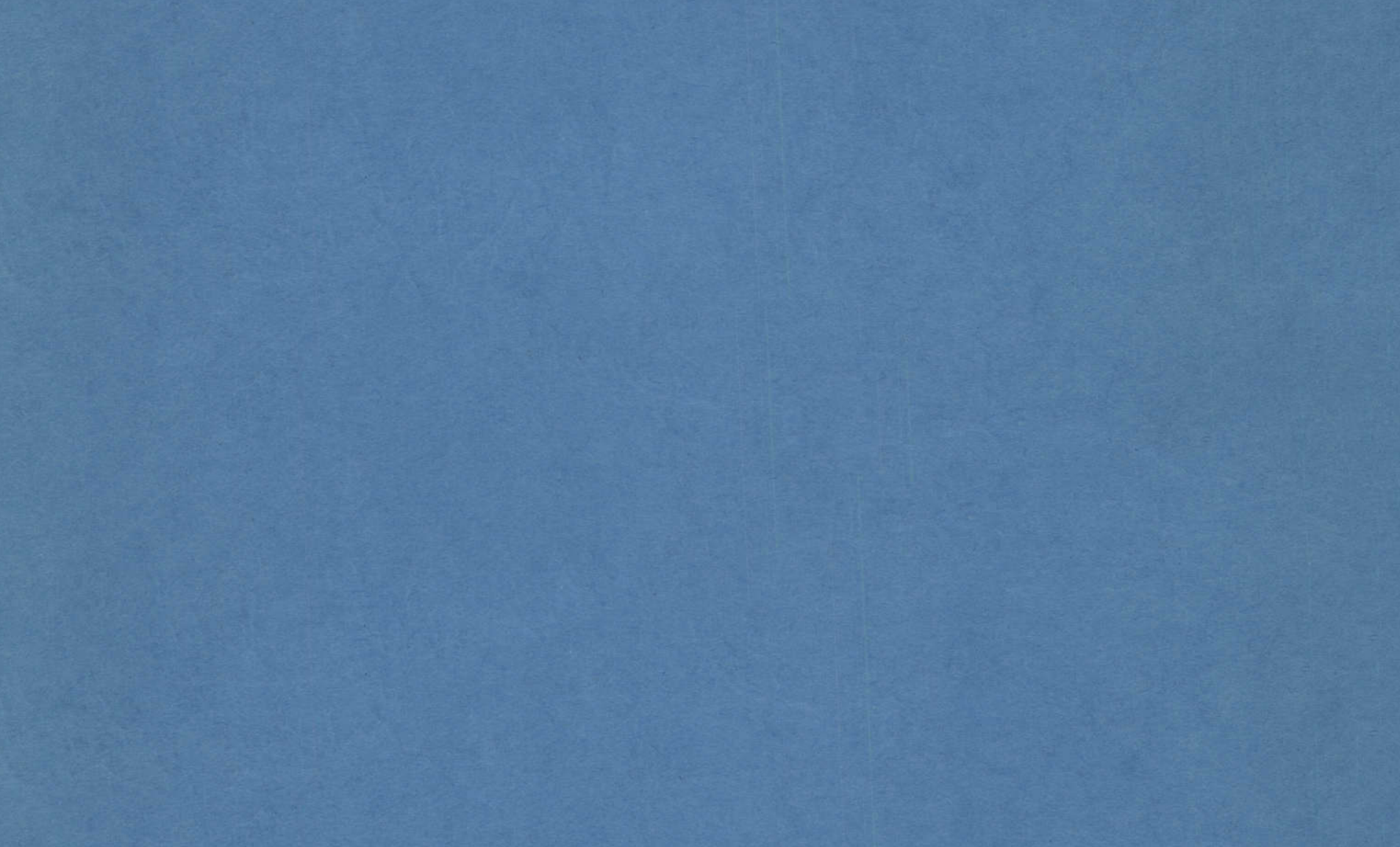

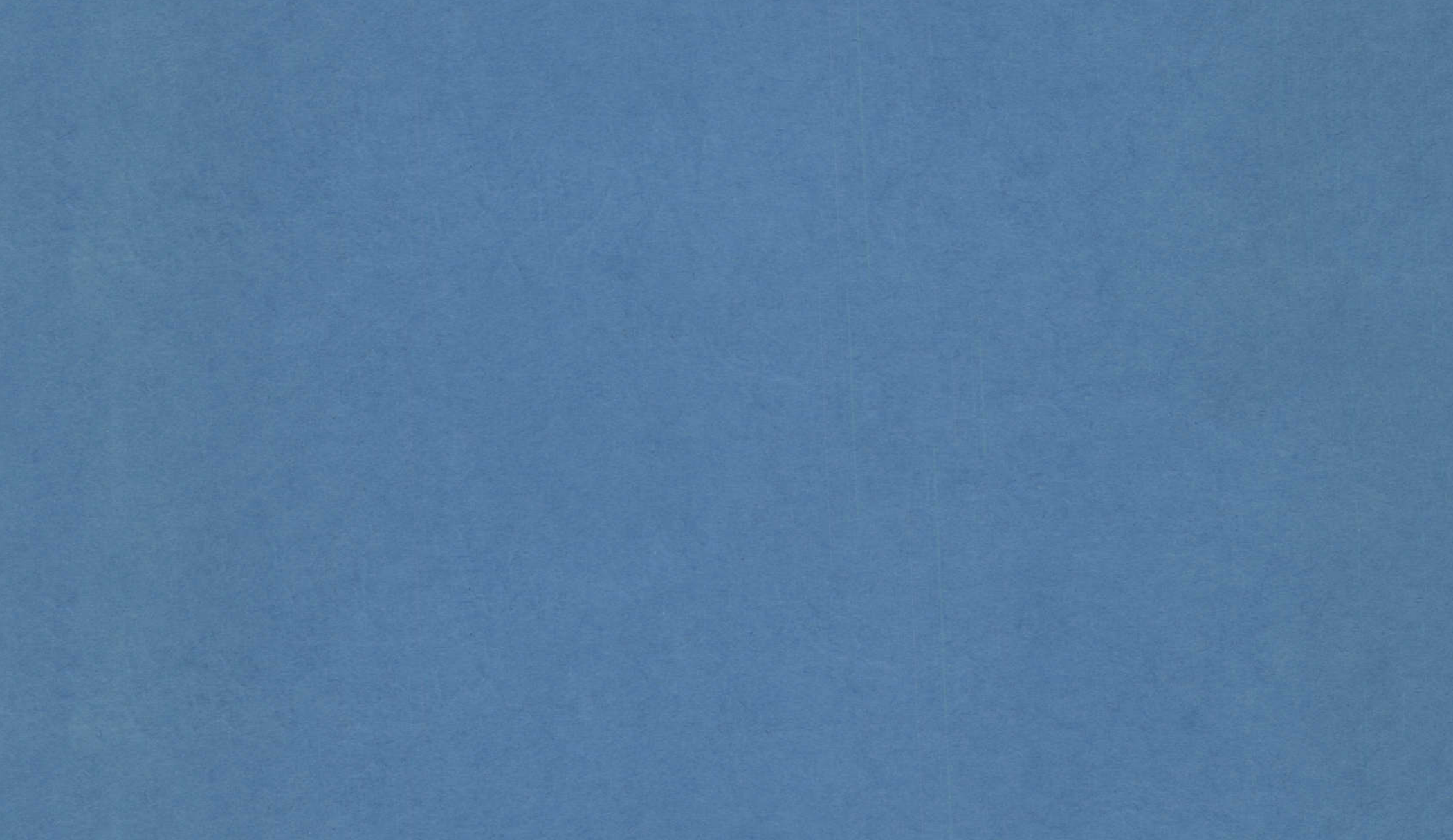

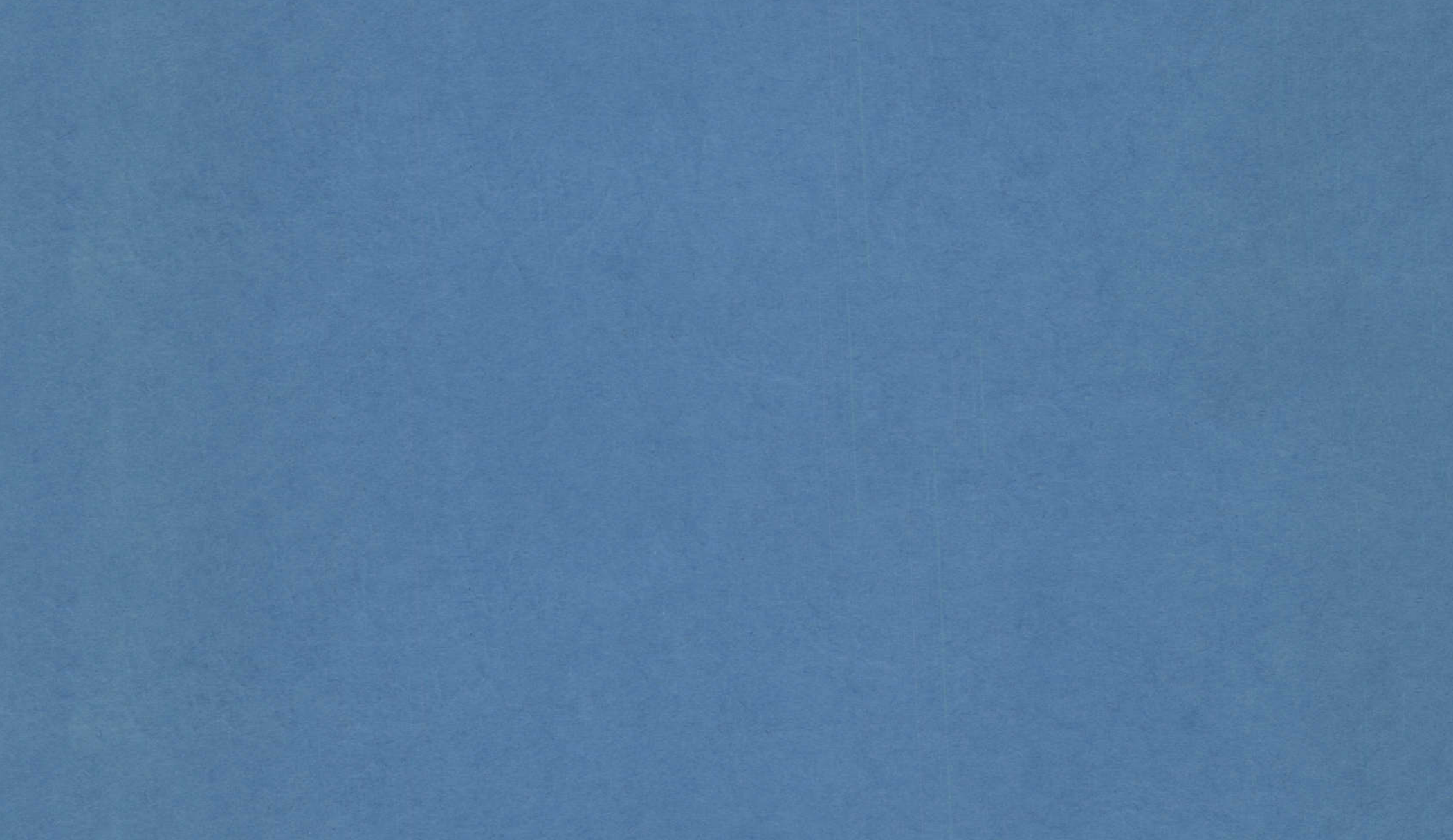

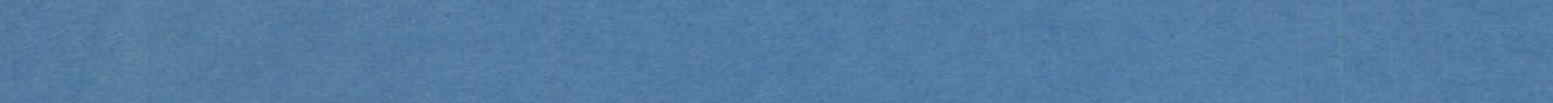
1. (3)

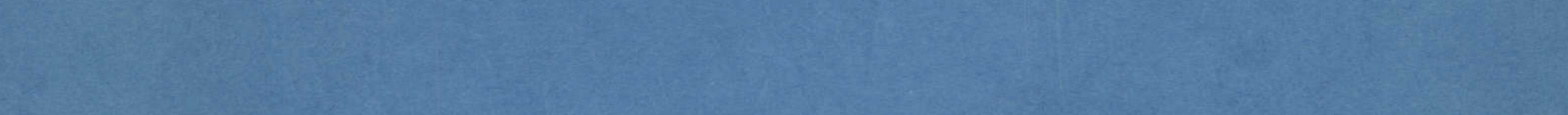

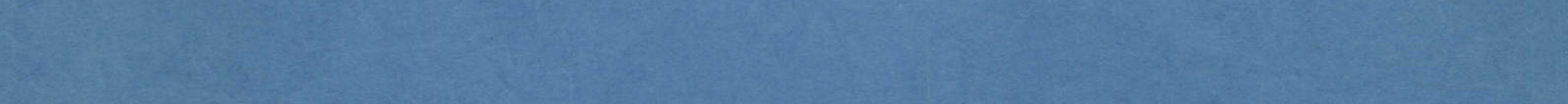
(1) 50 in and

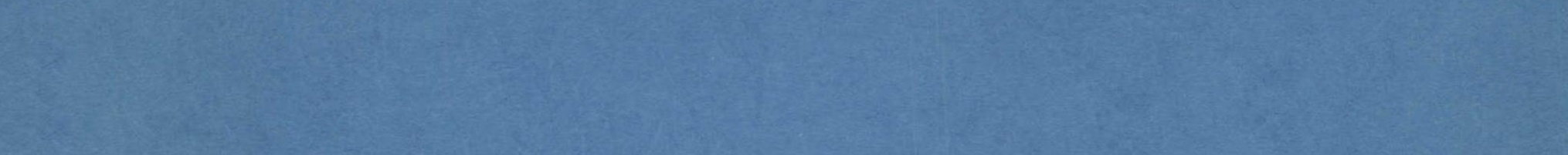


Approved for Issue: _.T. Eyrone
Date of Issue: November 15, 1952
Report Number: K- K-981

File Number: EPS $-X-172$

Subjoct Category: CHEMTSTRY

EVOLUTION OF HALIDES FROM HALOGENATED

PLASTICS EXXOSED TO GAMMA RADIATION

\author{
J. Byrne \\ W. L. Mann \\ T. W. Costikyan \\ C. B. Hanford \\ D. L. Johnson
}

Experimental Work and Preliminary Report By:

This report is distributed according to the category "Chemistry," as given in the "Distribution Lists for United States Atimie Energy Non-Classified Research and Development Reports, "TID-4500, July 15, 1952.

\author{
MASSACHUSETTS INSTITUTE OF TECHNOLOGY \\ Engineoring Practice School \\ Prepared from work performed ot the $X-10$ Plant of the \\ CARBIDE AND CARBON CHEMICALS DIVISION \\ Union Corbide and Carbon Corporation \\ Oak Ridge, Tennessee \\ Subcontract 70
}


Report Number: K-981

File Number: EPS-X-172

Date of Issue: November 15, 1952
Subject Category: CHEMISTRY

Title: Evolution of Halides From Halogenated Plastics Exposed to Gamma Radiation

Authors: J. Byrne

W. L. Mann

INTEERHAL DISTRIBUTION

1. J. C. Bowles

2. C. E. Center

3. S. Cromer

4. H. Ko Eister

5. J. M. Herndon

6. F。R. McQuilikin

7. F. S. Patton

8. F. L. Steahly

9. C. D. Watson

10. C. E. Winters

11. J. B. Sykes $(K-25 R C)$

12-15. J. B. Sykes (Files

16.19. ORNL Central F1les

20-31. M.I.T. Practice School

32-35. W. L. HarweII 
Report Number: K- $\underline{-91}$

File Number: EPS-X-172

Date of Issue: Hov, 15, 1952
Subject Category: CHEMISTRY

Title: Evolution of Halides From Halogenated Plastics Exposed to Gamma Radiation

Authors: J. Byrne

W. L. Mann

MASSACHIJSETIS INSTITUTE OF TECHNOLOGY

Engineering Practice School

I. ABSTRACT

The purpose of the investigation was to study the effects of ganma radiation from a cobalt -60 source on the physical properties and halogen evolution from the plastics polyvinyl chloride and polymonochlorotrifluoroethylene. Samples exposed for 2 to 28 days to a source of approximately 25,000 Roentgens per minute showed an appreciable evolution of both fluorine and chlorine. Tests on polyo monochlorotrifluoroethylene for tensile, impact, and shear strength showed rapidly decreasing values as the radiation exposure was increased. Similar physical tests on exposed polyvinyl chloride showed increased impact and shear strengths and a lower tensile strength. 
4.

ACKIOWLLDDEEMENT

The authors wish to express appreclation for the guidance and ald given by Mr. C. D. Watson of the Oak Ridge Nationel Laboratory. Thanks are also given to Carbide and Carbon Chemicals compary for making avallable the facilities and materials for this study. 
TABLE OF CONFIEHTS

I. ABSTRACT

Page

IT. STMUARY

II. SUMMARY

TII. TIIRODUCTION

IV. PROCEDURE

V. RESULTS

A. Experimental Data 11

B. Visual Observation $\quad 16$

$\begin{array}{ll}\text { VI. DISCUSSION OF RESULTS } & 17\end{array}$

A. Engineering Use of the Data 17

B. Significance of the Results from Fundamental 18 Viewpoint

C. Relative Release of Chlorine and Fluorine 19

D. Changes in Physical Properties 19

VII. CONCLUSIONS AND RECOMMEIDATIONS 21

VIII. APPENDIX 22

A. Summary of Data 22

B. Location of Original Data 22

C. Literature Citations 22 
TABIES AID FIGURES

TABLES

I

II

III

F IGURES

1

2

3

4
Page

16

23

23

Physlcal Properties

12

13

14

15 
II. SUMMARY

A study was made of the effect of cobalt-60 ganma radiation on the physical properties and halogen evolution from plasticized and nonplasticized polymonochlorotrifluoroethylene and non-plasticized polyvinyl chloride.

The cobalt-60 source, avallable at the Oak Ridge Hationsl Laboratory, radiated gamm energy at approximately 25,000 Roentgens per minute.

The study of halogen evolution from the plastics was conducted with one-eighth inch cubes and shavings of the materials. The samples were covered with a solution of sodium hydroxide and irradiated for periods of time from 2 to 28 days. The solution was analyzed for chloride ion and fluoride ion.

It was found that the samples consisting of shavings evolved more halogen than the cubes, indicating there had been a non-steady state condition in the cubes. The maximum rate of evolution was found to be nearly equal for the three plastic materials and was approximately 7 milifimoles of halide (total) per gram of sample exposed to a total radiation of one billion Roentgens.

Tensile, impact, and shear tests were conducted on specimens irras diated in the same source as chemical test specimens. All strengths of the polymonochlorotrifluoroethylene declined rapidly with radiation exposure. Polyvinyl chloride showed increased impact and shear strengths and a somewhat lower tensile strength after exposure.

It is recomnended that these results be considered when using these plastics for materials of construction in gamna-active processes. 


\section{INTRODUCTION}

Recently, Interest hos arisen in the changes of physical properties and halogen evolution of halogenated plastics subjected to gamma radiation. In equipment desigaed to handle radioactive materials, parts like goskets and bushings are frequently made from plastic materials, particularly chlorinated and fluorinated polymers which are ususlly chemically inert. In the presence of gamma radiation, a breakdown occurs with release and evolution of chlorine and fluo. rive, and a normally inert material becomes a source of corrosive agents.

Previous to this study, C.D.Watson (7) of the Oak Ridge National Laboratory conducted an investigation of the effects of ganma radiation on Tefion (polytetrafluorcethyleae) which is similar to Fivoro. thene (polymonochlorotrifluoroethylene) used in this study. An appreciable evolution of fluorine occurred.

Bopp and Sisman (2), and Bwrton (1), have made studies of the reactor radiation on some physical properties of a number of plastics. In such tests the specimens recelved a mixed irradiation of neutrons, beta and gamma rays. The results of Bopp and Sisman on vinylidene chloride (Saran) and polymonochlorotrifluoroethylene (Fluorothene) indicated a substantial diminution, or complete loss, of strength after accumulated exposure of $10^{17}$ to $10^{18}$ NVT units. The NVT unit is the product of neutron flux, neutrons/(sq.cm。 $)\left(\mathrm{sec}_{.}\right)$, and total time of exposure. Bopp and Sisman (2) estimated that during $10^{18}$ IVT wnits the mama-radiation exposure was 330 million Roentgens.

The planning of experiments and interpretation of the results required consideration of an unsteady-state mass transfer. In order to achieve a distinction necessery to discuss unsteady-state condition, release of halogen is rased to refer to the destruction of a chemical bond between the halogen and the polymer molecule; evolution of halogen is used to refer to the escape of halogen from the surfiace of the plastic object. It was assumed that the halogen was released from the chemical boud uniformly throughout the solid whereas the halogen evolved at the surface was at a small rate initially, increasing to constant value as steadyostate was attained. Since the "diffusion" of halogen through the plastic was considered to be very slow, the unsteady-state time was expected to be long. As developed in detail later, the results showed that unsteady-state existed throughout some of the tests. 
The data gathered were: (1) the evolution of halogen and (2) the changes in physical properties of plastics which had been exposed to gamma radiation.

The materials chosen for investigation were plasticized and nonplasticized polymonochlorotrifluoroethylene and a non-plasticized polyvinyl chloride. The polymonochlorotrifluoroethylene was manufactured by Carbide and Carbon Chemicals Company and is herein called by its trade name "Fluorothene" for convenience. The polyo vinyl chloride was obtained from the $V_{a n}$ Dorn Iron Works of Cleveland, Ohio, wader the trade ame "Lucoflex." The plasticlzer used for Fluorothene was a similar material of lower molecular weight. In sadition, a few samples of carbon tetrachloride were irradiated.

No attempt made to determine the chemical state of the halogen evol.ved. Hallde is used in reporting the results since the halogens were determined as halides in the analytical procedure. 
IV. PROCEDURE

The plastic materials were either cut into cubes, approximately oneeighth inch on a side, or were made into shavings, using a band saw. Samples of 1.0 to $2.5 \mathrm{gm}$. of cubes, and $0.5 \mathrm{gm}$. of shavings were weighed, placed into $10 \mathrm{ml}$. polystyrene vials, and covered with $10 \mathrm{ml}$. of sodium hydroxide solution. These samples were exposed for 2 to 28 days to game radiation from cobalt -60 at a nominal intensity of $25,000 \mathrm{R}$. $/ \mathrm{min}$. At intervals of about 48 hours, two vials of the cubes and one of the shavings were removed from the source. The caustic solution was withdrawn and analyzed for chlorine and fluorine in the case of Fluorothene, and chlorine only for the polyvinyl chloride samples. The analyses were made for elther halide after converting any hypohalite to the hallde form.

For comparative purposes, a few samples of carbon tetrechloride were irradiated to determine the evolution of halogen in a liquid system.

The changes in physical properties were observed by irradiation of additional samples prepared for shear, impact, and tensile tests. Bundles of these samples were exposed to gamma radiation and specimeas were removed at twouday intervals. The tests and sample shapes were similar to those of Bopp and Sisman (6). 
V. RESUTLTS

\section{A. Experimazts1 Datg}

The experimental results of balide evolntion are presented in Figures lo3 which show evolution as function of the radiation exposure. The choice of radiation exposure, rather than time, as the independent variable made on the sssunption that the release of halogen from the chemical bond is independent of intensity. The actus l intensities in these experimexts varied from 20,500 to $35,700 \mathrm{R}$. mix.g but the variation was not sufficiently exteasive to determine any effect of inteasity. The data were origingly plotted both against time and agsinst wecumileted exposure, and it appesren tost radistion exposure gave a lightly smoother appesrance to curves drawn through the data. Ia vien of the scatter of the points, wo defiaite conclusio mey be made.

The cblotide evolved from polyvinyl chloride is shown in Figure 1 for rediation exposures up to 1500 million $R$. for both cubes and shavings. The dsto for shaviags are represeated by a straight line, ladicating a steady-state condition; the data on cubss indicate botb in amount and curvature that unsteady ustate existed. The slope of the curve at $1100 \mathrm{mllilon} R$. Is approximstely cous to that of the straight lixe through the data on shaviogs.

The chloride and halide evolved from nod-plasticized Fluorothene are shown in Figwe 2, the ordinate representiag either chloride or fluoride. The ordinates for Flgures 2 and 3 are on a seale tenofold that of Figure 1. In view of the considerable scatter of the datas only one curve was drewn for cwbes and one for shavings, in effect taking the rate of evolution chloride and Iluoride to be equal. It is evident that mosteady-state existed throughout the experiments on culbes. The date on shavings show considerable scatter, but it seems likely that steady state was being asproabed at the higher exposwes.

The chloride and fluoride evolution from plasticized Fluorothene are shown in Figure 3 , the scale being the same as Figure 2. The data for shsvings colucide with those for non-plasticized Flnorothere. The cubes, however, showed a higher rate of evolution then for non plasticized material although steadyastate was not reached.

The charges in lupact, shear, and tensile streogths are shown in Figure 4 as a function of radiation exposure. The polyviryi chloride withstood the radiation better than the Fluorothene. The latter showed almost complete loss of strength at 200 million $R$. while polyriogl chloride ws useable after 800 million. $R$. 


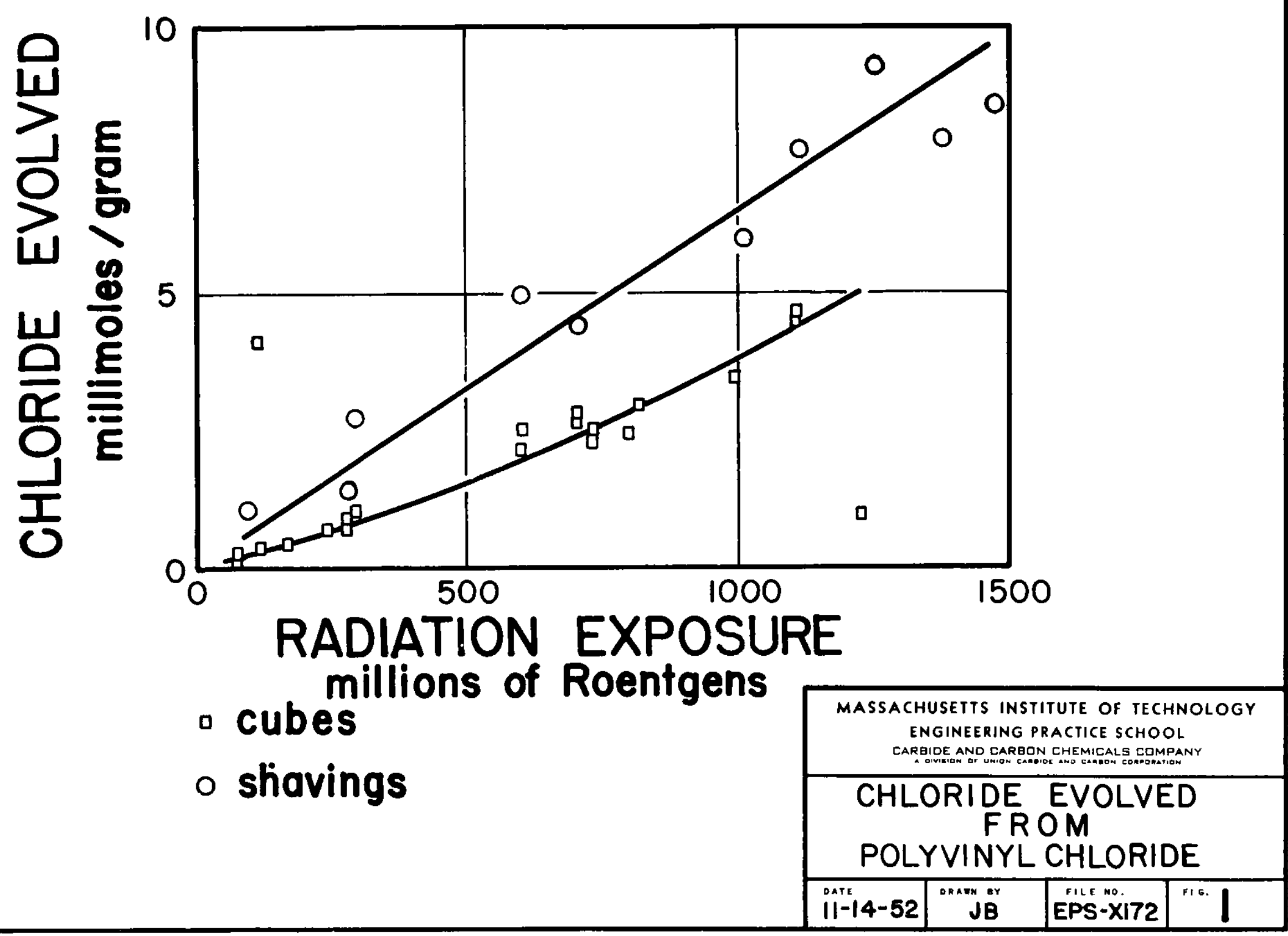




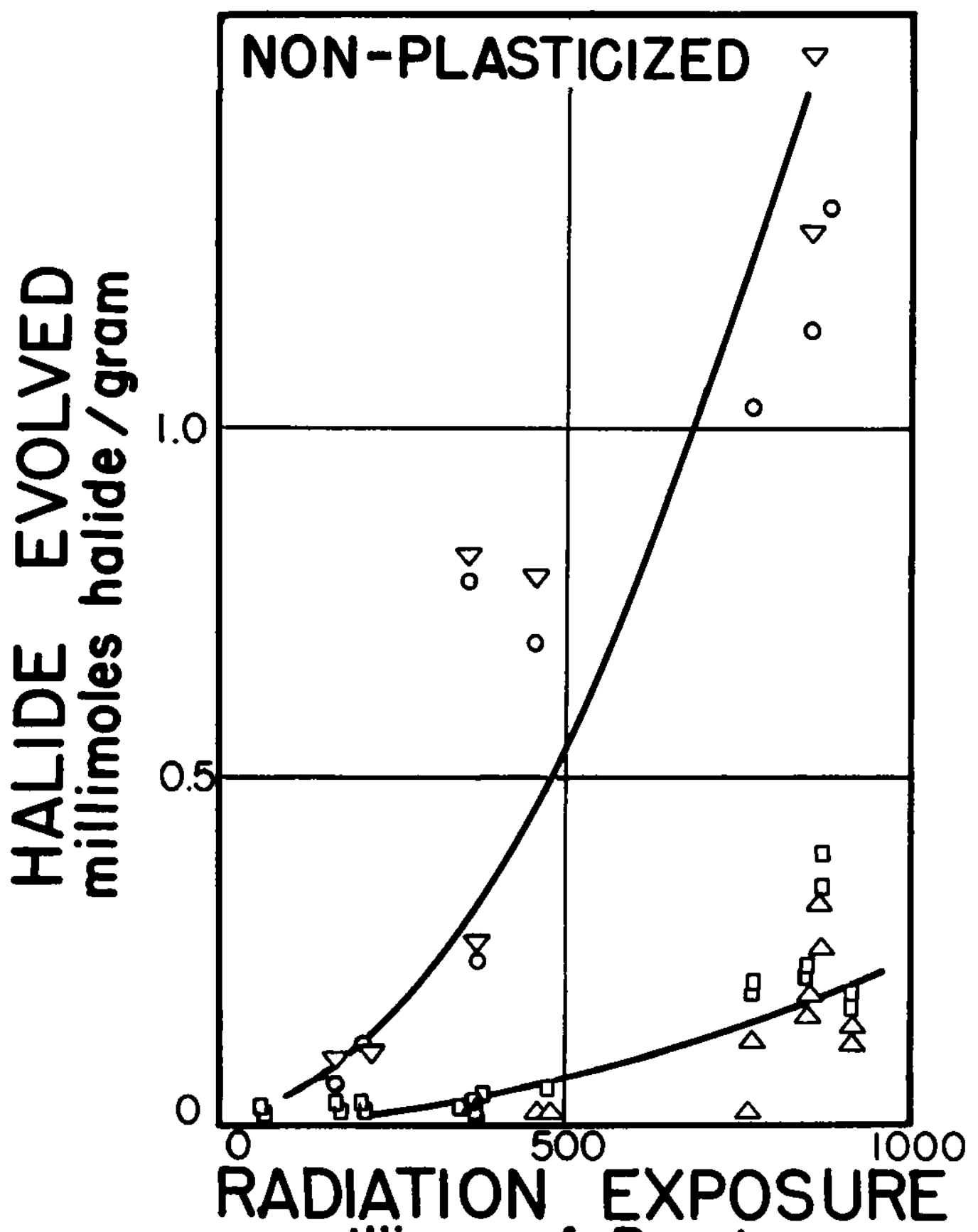

$\triangle \mathrm{Cl}^{-}$millions of Roentgens

$\triangle F^{-}$cubes

$\circ \mathrm{Cl}^{-}$shavings
$\nabla \mathrm{F}^{-}$

\begin{tabular}{|c|c|c|c|}
\hline \multicolumn{4}{|c|}{ 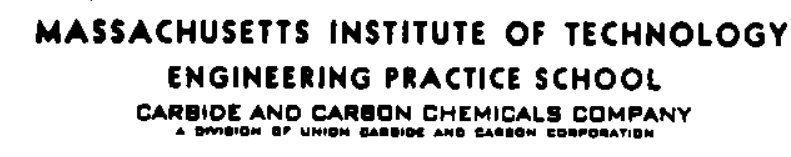 } \\
\hline \multicolumn{4}{|c|}{$\begin{array}{c}\text { HALIDES EVOLVED } \\
\text { FROM } \\
\text { FLUOROTHENE }\end{array}$} \\
\hline $1-14-52$ & J B & EPS-XI72 & 110.2 \\
\hline
\end{tabular}




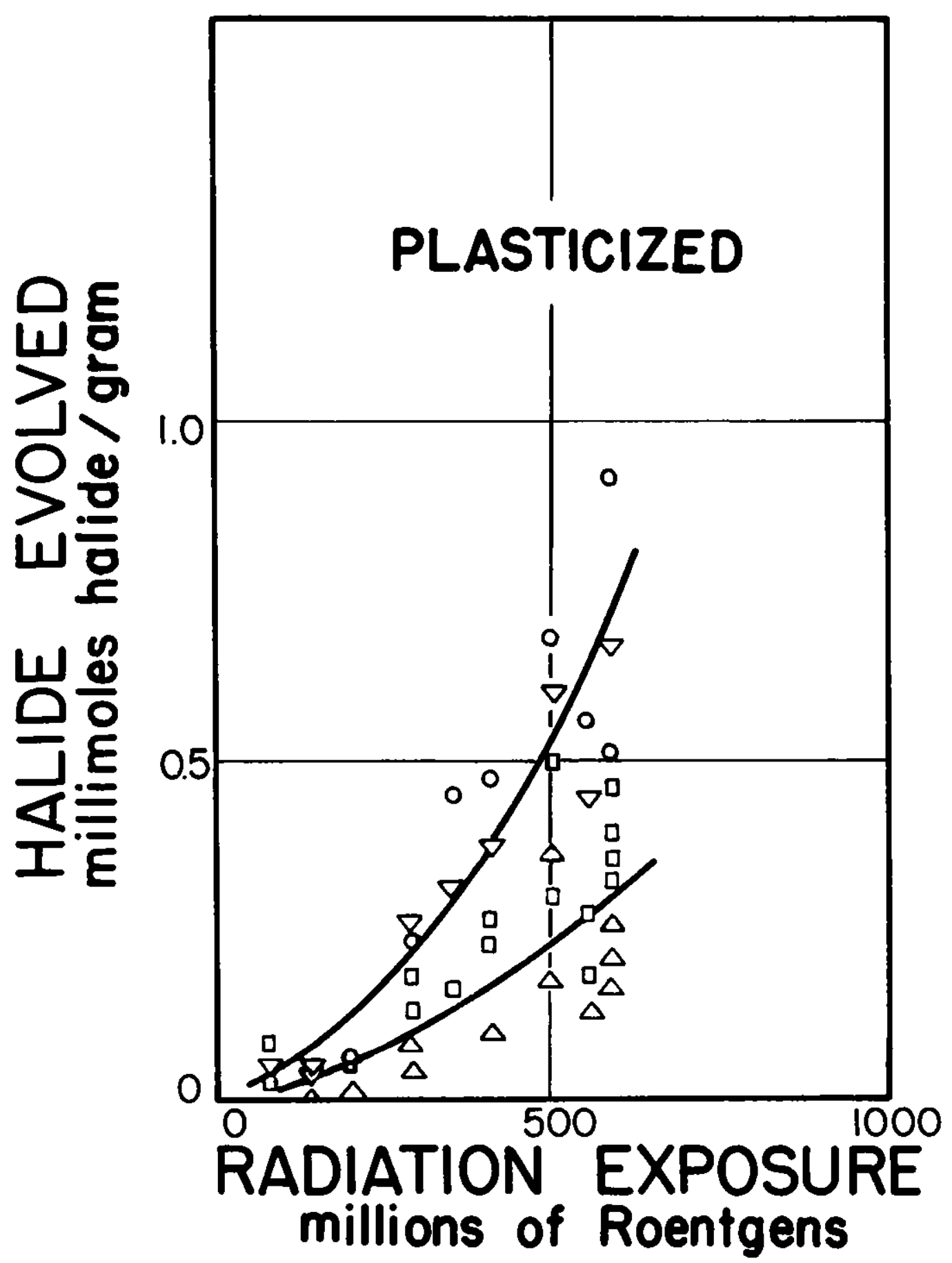

- $\mathrm{Cl}^{-}$

$\triangle F^{-}$Cubes

- $\mathrm{Cl}^{-}$

$\rightarrow \mathrm{F}^{-}$shavings

\begin{tabular}{|c|c|c|c|}
\hline \multicolumn{4}{|c|}{ 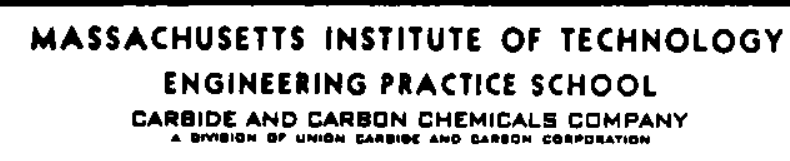 } \\
\hline \multicolumn{4}{|c|}{$\begin{array}{c}\text { HALIDES EVOLVED } \\
\text { FROM } \\
\text { FLUOROTHENE }\end{array}$} \\
\hline 52 & JB & $\mathrm{PS}^{\mathrm{E}} \mathrm{N}^{\mathrm{No}} \mathrm{XI72}$ & \\
\hline
\end{tabular}




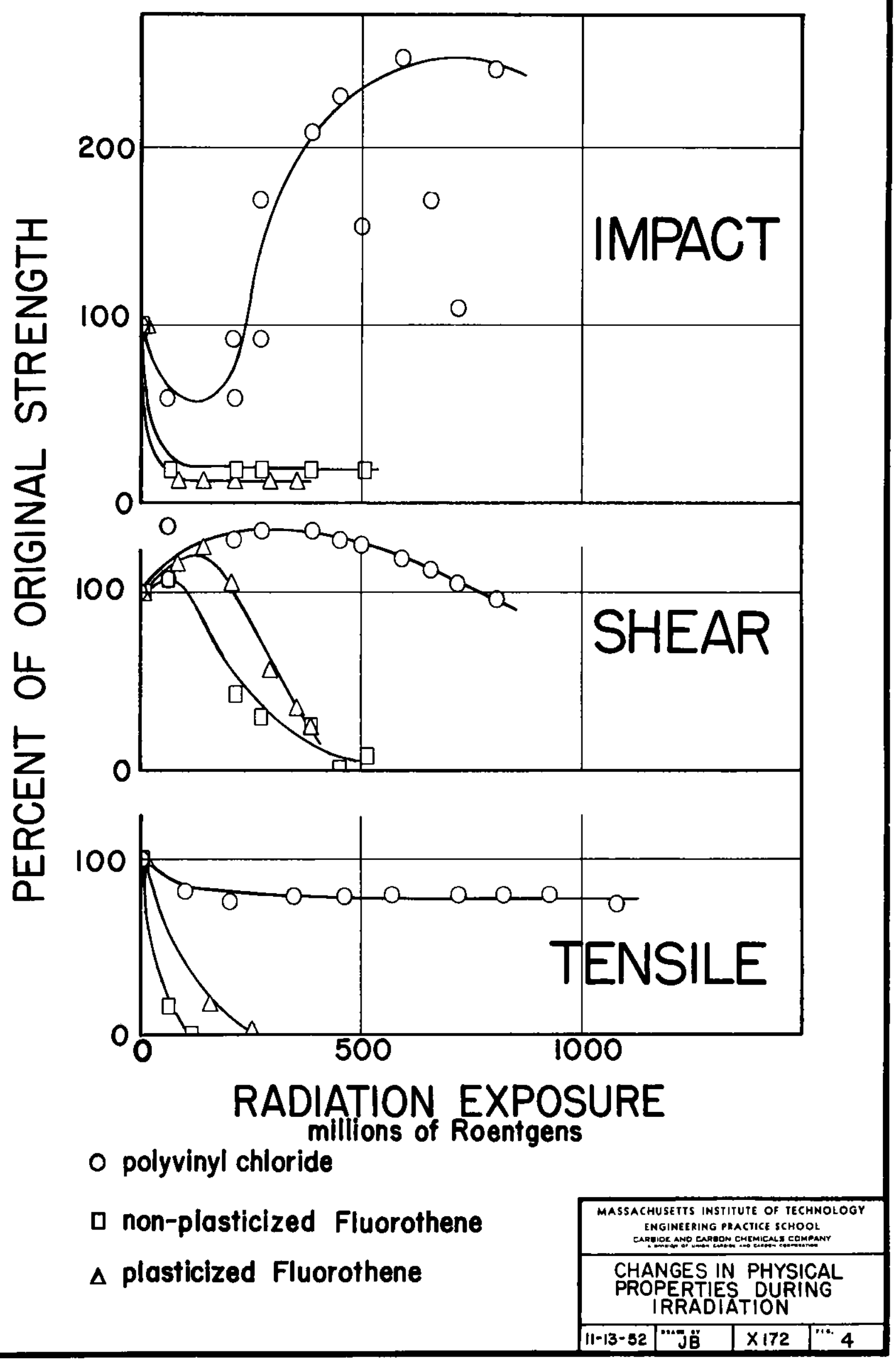


The maximum rates of halide evolution, shown in Table $I$, were obtained from the 8lopes of the curves drawn in Figures 1-3. The evolution of chloride from carbon tetrachloride is shown for comparison.

\section{B. Viswal Observations}

After two or four days of irradiation, the polyvinyl chloride turned from a trasaslucent light-brown to an opaque black. No further change in color occurred. Samples exposed longer than 20 days had blisters at the surface, some of which had evidently burst.

The Fluorothene became brittle after four days and remained so for 22 additional days. After still longer but unrecorded exposure, the non. plasticized Fluorothene became pliable and soft, somewhat like limp rubber.

\section{TABLE I}

MAXIMUM RATE OF HALOGEN EVOLUTION

\begin{tabular}{|c|c|c|c|c|c|}
\hline \multirow[t]{2}{*}{ Geometry } & \multirow[t]{2}{*}{$\begin{array}{l}\text { Halogen } \\
\text { Evolved }\end{array}$} & \multicolumn{4}{|c|}{$\begin{array}{l}\text { MAXIMUM RATE OF HALOGEIN BVOLOTION } \\
\text { millimoles hallde/(gm.)(bililon R.) }\end{array}$} \\
\hline & & $\begin{array}{r}\text { Carbon } \\
\text { tetra. } \\
\text { chloride }\end{array}$ & $\begin{array}{l}\text { Plasticized } \\
\text { Fluorothene }\end{array}$ & $\begin{array}{l}\text { Non-plasticized } \\
\text { Fluorothene }\end{array}$ & $\begin{array}{r}\text { Polyvinyl } \\
\text { Chloride }\end{array}$ \\
\hline \multirow[t]{2}{*}{ CUBES } & $\begin{array}{l}\text { Fluoride } \\
\text { Chloride }\end{array}$ & & 1 & $\begin{array}{l}0.4 \\
0.4\end{array}$ & 7 \\
\hline & Total hal & & 2 & 0.8 & 7 \\
\hline \multirow[t]{2}{*}{ SHAVIMGS } & $\begin{array}{l}\text { Fluoride } \\
\text { chloride }\end{array}$ & & $\begin{array}{l}2.5 \\
2.5\end{array}$ & $\begin{array}{l}3 \\
3\end{array}$ & 7 \\
\hline & Total hal & & 5 & 6 & 7 \\
\hline I.IQUID & & 9 & & & \\
\hline $\begin{array}{l}\text { MAXIMUTM R } \\
\text { IRRESPECI } \\
\text { OF GEOMET }\end{array}$ & $\begin{array}{l}\text { Motal } \\
\text { HalIde }\end{array}$ & 9 & 5 & 6 & 7 \\
\hline
\end{tabular}




\section{DISCUSSION OF RESULTS}

\section{A. Englneering Use of the Data}

The amount of hallde evolved during the physical lifetime of the materials can be tolerated in some systems and not in others. There are two important reasons for concern about halides evolved: (1) excessive corrosion resulting in physical weakness or leaks and (2) contamination of process materials by corrosion products. The data reported here can be used to estimate the order of magnitude of both the amount of corrosion and the amount of contamination.

For example, consider corrosion of an iron surface in contact with a gasket $2 \mathrm{~mm}$. thick. Assume that: (1) the evolution occurs at the maximum rate reported in Table $I$, namely, 7 millimoles/(gm.)(billion $R_{0}$ ); (2) each mole of halide removes one-half mole of iron; (3) the attack is unfform and occurs at point where the halogen is evolved; (4) only gamma radiation is present at an intensity of $1000 \mathrm{R}$./min.; and (5) evolution is equal on each face of the gasket. The calculation is show below using a basis of one square centimeter imagined to be in the center of a large area of gasket material.

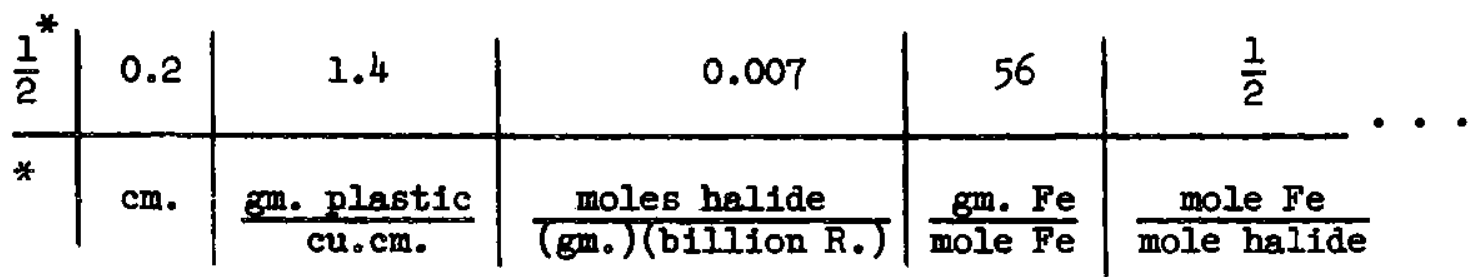

\begin{tabular}{c|c|c|cc}
$\frac{1}{7.8}$ & 1000 & 525,600 & $\frac{1}{2.54}$ \\
\hline$\frac{\mathrm{cu} . \mathrm{cm}}{\mathrm{gm}_{0} \mathrm{Fe}}$ & $\frac{\mathrm{R}_{0}}{\mathrm{~min}}$ & $\frac{\mathrm{min} \cdot}{\mathrm{yr} \cdot}$ & $\frac{1 \mathrm{n} .}{\mathrm{cm}}$
\end{tabular}

*Dimensionless correction for two surfaces, assuming that half of the halogen released leaves one surface.

Thus the calculated corrosion rate is 0.0007 inches per year $(0.7$ mils) and the contamination is approximately 1 millimole halide and 0.5 millimole iron per year. In this example the use of polyvinyl chloride seems reasonable since the contamination would in most cases be trivial, and the physical life of the material would be more than two years. On the other hand, Fluorothene would withstand the radiation only a few months. The rate of corrosion is within limits normally considered acceptable. 
An Inherent assumption made in the above calculation is that the evolution is Independent of intensity of radiation. In view of the assumption (already made) that release for a given exposure is independent of intensity, It is evident that during unsteady-state the evolution for a given exposure will be a function of intensity. In the case of a high rate of irradiation, for example, the release would occur rapidly, but the diffusion would proceed in the same mode as for other latensities. From separate samples which had recelved equal total exposure at different intensities, the following comparisons are made: (1) at the end of irradiation, the amount of halogen evolved would be greater from the sample irradiated at lower Intensity; and (2) at any given time, the amount of halogen evolved would be greater from the sample irradiated at the higher intensity. For construction purposes, the unsteady-state condition is advantageous, for as long as the released halogen is "stored" within the plastic, corrosion and contamination cannot occur. There are not, however, sufficlent data available to permit estimation of the extent of storage in systems of geometry different from the experimental samples.

For engineering purposes, a conservative assumption for the amount of evolution may be based on the maximum rates shown in Table $I$. It is recommended that the data presented in this report be considered when using polyvinyl chloride and Fluorothene, or similar materials, in the construction of systems to handle gamma-active materials.

B. Significance of the Results from a Fundamental V1ewpoint

While the objective of the work was to obtain engineering data on evolution, the release of the halogens from the chemical bond is of fundamental interest. There are, however, two principal difficulties in interpreting these data: (1) the unsteadyostate condition and (2) the determination of the gamma-energy absorbed.

1. Unsteady-state Considerations

The data obtained give clear indication that unsteady state existed throughout most of the experiments with cubes and in some experiments with shavings. Indications of steady state were considered to be: constant slope of the curve of halide evolution as a function of radiation exposure and slope of the curve for cubes equal to that of shevings with both slopes belng constant.

If certain simplifying assumptions are made, it is possible to write a differential equation relating evolution, release, and time. The assumptions used were: (1) space-uniform release of the halogen from the chemical bond; (2) diffusion of the halogen (in unspectfied form) in a manner proportional to the concentration, with a constant diffusion coefficient which is neither a function of time nor radiation exposure; (3) constant radiation intensity; and (4) no resistance to escape of 
the halogen at the surface of the solld. It would be possible to solve the equation by numerical methods, but the solution is too tedious for hand calculation. Machine calculation was deemed uawar. ranted since the assumption of a constant diffusion coefficlent is not realistic. Bubbles appeared at the surface of the plastic, some of which had evidently burst, and some surface cracks were visible. Bubbles and cracks in the plastic would change the diffusion coefficlent and surface area making the equation inappropriate. The scatter of the data may reasonably be attributed to such deformations. It is evident that fundamental studies of reaction mechanism mast be based on experiments different in method and precision.

No attempt has been made to estimate the amount of gamma energy actually absorbed in the plastic, and no estimate of the energy involved in breaking the chemical bond can be made from these data. Since the gamma absorptivity of the plastic is small, the amount of absorption would necessarily require an indirect technique.

The assumption of space-uniform release, postulated above, is based on the small absorption of gamma in the plastic material; namely, the ganma intensity is assumed uniform throughout the material, and the release is assumed proportional to intensity.

C. Relative Release of Chlorine and Fluorine

The data for shavings in Figures 2 and 3 , and Table $I$, show a nearly equal maximum rate of evolution of chlorine and fluorine on a molar basis, although the Fluorothene contains a ratio of three moles fluorine to one mole of chlorine. If this result is significant, two explanations seem plausible: (1) fluorine is less readily released or (2) the fluorine, once released, displaces the chlorine. The choice of explanations is complicated by the result that the maximam rate of chloride release from polyvinyl chloride and carbon tetrachloride is approximately equal to the maximum rate of total hallde release from Fluorothene. It is evident further experiments w1ll be necessary to resolve questions of relative rates of release.

\section{Changes in Physical Properties}

The polyvinyl chloride survived exposure better than Fluorothene and actually showed substantial lmorovement in shear and impact strength during part of the experimentation. The improvement possibly resulted from plasticization by smaller molecules produced by splitting of the polymer chain. Simflar improvement in impact strength was noted by Bopp and isisman(3) for polytetrafluoroethylene (Teflon).

The changes in the physical properties of non-plasticized Fluorothene are similar to those found by Bopp and Sisman for reactor radiation (2). 
Complete loss of strength occurred in the reactor after exposure estimated to be 50 million $\mathrm{R}$. of gamma, plus beta and neutron irradiation. In these experiments with gamma alone, complete fallure occurred at 100-200 mililon $R_{0}$, indicating that beta and neutron irradiation as well as gamma are harmful.

It is worth noting that Bopp and Sisman (5) found some materials, e.g. polystyrene, which were unchanged in strength after prolonged radiation. Consequently the data reported here on physical properties must be considered specific for the materials studied. 
VII. CONCLUSIONS AND RECOMMENDATIONS

It was concluded that:

1. When polymonochlorotrifluoroethylene (Fluorothene) and polyvinyl chloride are exposed to gamma radiation, the quantities of halogen evolved may be sigaificant from corrosion and contamination viewpoints.

2. For engineering purposes, the rate of evolution can be taken as 7 millimoles of hallde per gram of material per billion Roentgens of exposure.

3. Polyvinyl chloride retained physical strength better than polymonochlorotrifluoroethylene during exposure to ganma radiation.

It is recommended that the data presented in this report be used when considering polyvinyl chloride or Fluorothene as construction materials in gamma-active systems. 
VIII. APPENDIX

A. SUMMARY OF DATA

Tables II and III are presentations of the experimental data and calculated values.

\section{B. LOCATION OF ORIGITAL DATA}

The original data are recorded in Notebook No. 1879 which is on file at the M.I.T. Engineering Practice School, K-25, Oak Ridge, Tennessee.

\section{LITERATURE CITAMIONS}

1. Burton, M., J. Phys. and Collo1d Chem. 51, 786, (1947).

2. Sisman, 0., and Bopp, C. D., Physical Properties of Irradiated Plastics, Report No. ORNL-928, p. 9, Oak RIdge National Laboratory Carbide and Carbon Chemicals Company, 1951.

3. Ibid., p. 85.

4. To1d., p. 90 .

5. Ibid., p. 166.

6. Ib1d., p. 202 .

7. Watson, C. D., umpublished data, personal comunication, April 1952. 
TABLE II

HALOGEN EVOLUTION

\begin{tabular}{|c|c|c|c|c|c|}
\hline $\begin{array}{c}\text { Sample } \\
\text { No. }\end{array}$ & $\begin{array}{l}\text { Radiation } \\
\text { Intensity }\end{array}$ & $\begin{array}{l}\text { Time of } \\
\text { Irradiation }\end{array}$ & $\begin{array}{c}\text { Total } \\
\text { Radiation } \\
\text { Exposure }\end{array}$ & $\begin{array}{r}\text { Chloride } \\
\text { Evolved }\end{array}$ & $\begin{array}{c}\text { Fluoride } \\
\text { Evolved } \\
\end{array}$ \\
\hline & $\begin{array}{l}\text { (Thousands of } \\
\text { Roentgens) } \\
\text { min. }\end{array}$ & Hours & $\begin{array}{l}\text { Millions of } \\
\text { Roentgens }\end{array}$ & $\frac{\text { Millimole Cl}}{\text { gm. }}$ & $\frac{\text { Millimole } F^{-}}{\mathrm{gmo}^{-}}$ \\
\hline
\end{tabular}

Polyvinyl Chloride
Samples 1-20 Cubes Samples 21-30 Shavings

\begin{tabular}{rrrrl}
1 & 29.0 & 43 & 75 & 0.234 \\
2 & 35.7 & 138 & 286 & 1.078 \\
3 & 29.0 & 67 & 116 & 0.367 \\
4 & 29.0 & 161 & 280 & 0.888 \\
5 & 35.7 & 281 & 602 & 2.18 \\
6 & 35.7 & 329 & 704 & 2.76 \\
7 & 29.0 & 425 & 739 & 2.55 \\
8 & 29.0 & 474 & 823 & 3.0 \\
9 & 29.0 & 578 & 100 & 3.76 \\
10 & 35.7 & 521 & 1114 & 4.72 \\
11 & 29.0 & 43 & 75 & 0.147 \\
12 & 29.0 & 138 & 241 & 0.739 \\
13 & 29.0 & 161 & 280 & 0.795 \\
14 & 35.7 & 281 & 602 & 2.58 \\
15 & 29.0 & 67 & 116 & 4.11 \\
16 & 29.0 & 424 & 739 & 2.35 \\
17 & 35.7 & 329 & 704 & 2.76 \\
18 & 35.7 & 576 & 1232 & 1.025 \\
19 & 29.0 & 462 & 802 & 2.48 \\
20 & 35.7 & 521 & 1114 & 4.52 \\
21 & 35.7 & 43 & 92 & 1.095 \\
22 & 35.7 & 138 & 286 & 2.74 \\
23 & 35.7 & 329 & 704 & 4.52 \\
24 & 35.7 & 281 & 1602 & 5.0 \\
25 & 35.7 & 588 & 1260 & 9.31 \\
26 & 35.7 & 474 & 1013 & 6.15 \\
27 & 29.0 & 161 & 280 & 1.405 \\
28 & 35.7 & 690 & 1475 & 8.58 \\
29 & 35.7 & 521 & 1114 & 7.74 \\
30 & 35.7 & 642 & 1372 & 7.92 \\
\hline
\end{tabular}

Non-plasticized Fluorothene
Samples P1-P2O Cubes Samples P21-P30 Shavings

\begin{tabular}{llllll} 
P1 & 20.5 & 54 & 66 & 0.0282 & 0.0034 \\
P2 & 29.0 & 102 & 177 & 0.013 & 0.0058 \\
P3 & 35.7 & 221 & 475 & 0.051 & 0.011 \\
P4 & 35.7 & 169 & 382 & 0.045 & 0.035 \\
P5 & 29.0 & 121 & 211 & 0.027 & 0.0079 \\
P6 & 29.0 & 216 & 377 & 0.027 & 0.014 \\
P7 & 35.7 & 361 & 773 & 0.197 & 0.12 \\
P8 & 35.7 & 409 & 877 & 0.347 & 0.26 \\
P9 & 29.0 & 529 & 920 & 0.186 & 0.12 \\
P10 & 29.0 & 494 & 858 & 0.226 & 0.19 \\
P11 & 20.5 & 54 & 66 & 0.016 & 0.025 \\
P12 & 29.0 & 102 & 177 & 0.012 & 0.052 \\
P13 & 35.7 & 221 & 474 & 0.031 & 0.016 \\
P14 & 35.7 & 169 & 361 & 0.022 & 0.026 \\
P15 & 29.0 & 121 & 210 & 0.012 &.---1 \\
P16 & 29.0 & 216 & 376 & 0.012 & 0.012 \\
P17 & 35.7 & 361 & 773 & 0.19 & 0.016 \\
P18 & 35.7 & 409 & 877 & 0.395 & 0.32 \\
P19 & 29.0 & 529 & 920 & 0.18 & 0.14 \\
P20 & 29.0 & 494 & 858 & 0.21 & 0.16 \\
P21 & 20.5 & 54 & 66 & - & - \\
P22 & 29.0 & 102 & 177 & 0.062 & 0.095 \\
P23 & 35.7 & 221 & 453 & 0.690 & 0.785 \\
P24 & 35.7 & 169 & 361 & 0.781 & 0.815 \\
P25 & 29.0 & 121 & 211 & 0.114 & 0.118 \\
P26 & 29.0 & 216 & 377 & 0.24 & 0.26 \\
P27 & 35.7 & 361 & 773 & 1.03 & 0.25 \\
P28 & 35.7 & 409 & 877 & 1.32 & 1.54 \\
P29 & 29.0 &..- & 858 & 1.14 & 1.28 \\
P30 & 29.0 & 494 &.--- &.-- & - \\
\hline
\end{tabular}

Plasticized Fluorothene
Samples F1-F20 Cubes Samples F21-F30 Shavings

$\begin{array}{rrrrll}\text { F1 } & 20.5 & 67 & 82.1 & 0.0965 & -.- \\ \text { F2 } & 20.5 & 120 & 148 & 0.0781 & 0.0172 \\ \text { F3 } & 20.5 & 168 & 207 & 0.114 & 0.0518 \\ \text { F4 } & 20.5 & 240 & 296 & 0.135 & 0.0385 \\ \text { F5 } & 20.5 & 288 & 354 & 0.167 & 0.0658 \\ \text { F6 } & 20.5 & 336 & 413 & 0.266 & 0.1005 \\ \text { F7 } & 20.5 & 408 & 502 & 0.303 & 0.187 \\ \text { F8 } & 20.5 & 456 & 562 & 0.275 & 0.196 \\ \text { F9 } & 20.5 & 475 & 596 & 0.460 & 0.208 \\ \text { F10 } & 20.5 & 475 & 596 & 0.326 & 0.195 \\ \text { F11 } & 20.5 & 67 & 82 & 0.0236 & --.- \\ \text { F12 } & 20.5 & 120 & 148 & 0.0455 & 0.0137 \\ \text { F13 } & 20.5 & 168 & 207 & 0.0541 & 0.0177 \\ \text { F14 } & 20.5 & 240 & 296 & 0.186 & 0.0742 \\ \text { F15 } & 20.5 & 288 & 354 & 0.153 & -.-1 \\ \text { F16 } & 20.5 & 336 & 413 & 0.228 & 0.0926 \\ \text { F17 } & 20.5 & 408 & 502 & 0.499 & 0.363 \\ \text { F18 } & 20.5 & 456 & 562 & 0.185 & 0.128 \\ \text { F19 } & 20.5 & 475 & 596 & 0.398 & 0.262 \\ \text { F20 } & 20.5 & 475 & 596 & 0.356 & 0.165 \\ \text { F21 } & 20.5 & 67 & 82 & 0.0505 & 0.0579 \\ \text { F22 } & 20.5 & 120 & 148 & 0.0521 & 0.0431 \\ \text { F23 } & 20.5 & 168 & 207 & 0.055 & 0.120 \\ \text { F24 } & 20.5 & 240 & 296 & 0.336 & 0.267 \\ \text { F25 } & 20.5 & 288 & 354 & 0.451 & 0.318 \\ \text { F26 } & 20.5 & 336 & 413 & 0.474 & 0.379 \\ \text { F27 } & 20.5 & 408 & 502 & 0.685 & 0.600 \\ \text { F28 } & 20.5 & 456 & 562 & 0.558 & 0.448 \\ \text { F29 } & 20.5 & 475 & 596 & 0.920 & 0.779 \\ \text { F30 } & 20.5 & 475 & 596 & 0.513 & 0.374\end{array}$


TABLE III

PHYSICAL PROPERTIES

\begin{tabular}{|c|c|c|c|c|c|c|}
\hline $\begin{array}{l}\text { Sample } \\
\text { No. }\end{array}$ & $\begin{array}{l}\text { Radiation } \\
\text { Intensity }\end{array}$ & $\begin{array}{l}\text { Time of } \\
\text { Irradiation }\end{array}$ & $\begin{array}{c}\text { Total } \\
\text { Radiation } \\
\text { Exposure }\end{array}$ & $\begin{array}{l}\text { Indicator } \\
\text { Reading }\end{array}$ & $\begin{array}{c}\text { Breaking } \\
\text { Load }\end{array}$ & $\begin{array}{l}\text { Percent of } \\
\text { Original } \\
\text { Strength }\end{array}$ \\
\hline & $\begin{array}{l}\text { (Thousands of } \\
\frac{\text { Roentgens) }}{\text { (m1n.) }}\end{array}$ & Hours & $\begin{array}{l}\text { Millions of } \\
\text { Roentgens }\end{array}$ & $\begin{array}{l}\text { Dimension- } \\
\text { less }\end{array}$ & (lb.) & \\
\hline \multicolumn{7}{|c|}{$\begin{array}{c}\text { IMPACT TEST } \\
\text { Polyvinyl Chloride }\end{array}$} \\
\hline $\begin{array}{l}\text { Blank } \\
\text { Al-A4 } \\
\text { A5-A8 } \\
\text { A9-A12 }\end{array}$ & $\begin{array}{l}0 \\
20.6 \\
20.6 \\
20.6\end{array}$ & $\begin{array}{r}0 \\
52 \\
172 \\
220\end{array}$ & $\begin{array}{r}0 \\
65 \\
213 \\
273\end{array}$ & $\begin{array}{l}0.092 \\
0.054 \\
0.085 \\
0.156\end{array}$ & & $\begin{array}{r}100 \\
59 \\
92 \\
170\end{array}$ \\
\hline $\begin{array}{l}\text { A13-A16 } \\
\text { A17-A20 } \\
\text { A21-A24 } \\
\text { A25-A28 }\end{array}$ & $\begin{array}{l}20.6 \\
20.6 \\
20.6 \\
20.6\end{array}$ & $\begin{array}{l}316 \\
365 \\
411 \\
480\end{array}$ & $\begin{array}{l}391 \\
452 \\
507 \\
594\end{array}$ & $\begin{array}{l}0.192 \\
0.210 \\
0.143 \\
0.229\end{array}$ & & $\begin{array}{l}208 \\
228 \\
155 \\
248\end{array}$ \\
\hline $\begin{array}{l}\text { A29-A32 } \\
\text { A33-A36 } \\
\text { A37-A40 }\end{array}$ & $\begin{array}{l}20.6 \\
20.6 \\
20.6\end{array}$ & $\begin{array}{l}534 \\
582 \\
654\end{array}$ & $\begin{array}{l}660 \\
720 \\
810\end{array}$ & $\begin{array}{l}0.156 \\
0.101 \\
0.225\end{array}$ & & $\begin{array}{l}169 \\
110 \\
244\end{array}$ \\
\hline \multicolumn{7}{|c|}{ Non-plasticized Fluorothene } \\
\hline $\begin{array}{l}\quad \text { Blank } \\
\text { B1-B4 } \\
\text { B5-B8 } \\
\text { B9-B12 }\end{array}$ & $\begin{array}{l}0 \\
20.6 \\
20.6 \\
20.6\end{array}$ & $\begin{array}{r}0 \\
52 \\
172 \\
220\end{array}$ & $\begin{array}{r}0 \\
65 \\
212 \\
271\end{array}$ & $\begin{array}{l}0.221 \\
0.045 \\
0.046 \\
0.043\end{array}$ & & $\begin{array}{r}100 \\
20 \\
21 \\
20\end{array}$ \\
\hline $\begin{array}{l}\text { B13 } \\
\text { B21-B24 }\end{array}$ & $\begin{array}{l}20.6 \\
20.6\end{array}$ & $\begin{array}{l}316 \\
411\end{array}$ & $\begin{array}{l}388 \\
514\end{array}$ & $\begin{array}{l}0.046 \\
0.045\end{array}$ & & $\begin{array}{l}21 \\
20\end{array}$ \\
\hline \multicolumn{7}{|c|}{ Plasticized Fluorothene } \\
\hline $\begin{array}{l}\text { C1-C4 } \\
\text { C5-C8 } \\
\text { C9-C12 } \\
\text { C13-C16 }\end{array}$ & $\begin{array}{l}0 \\
20.6 \\
20.6 \\
20.6\end{array}$ & $\begin{array}{r}0 \\
72 \\
119 \\
168\end{array}$ & $\begin{array}{r}0 \\
89 \\
147 \\
207\end{array}$ & $\begin{array}{l}0.267 \\
0.034 \\
0.034 \\
0.033\end{array}$ & & $\begin{array}{l}10 C \\
13 \\
13 \\
12\end{array}$ \\
\hline $\begin{array}{l}\mathrm{C} 17-\mathrm{C} 20 \\
\mathrm{C} 21-\mathrm{C} 24\end{array}$ & $\begin{array}{l}20.6 \\
20.6\end{array}$ & $\begin{array}{l}240 \\
288\end{array}$ & $\begin{array}{l}295 \\
354\end{array}$ & $\begin{array}{l}0.034 \\
0.035\end{array}$ & & $\begin{array}{l}13 \\
13\end{array}$ \\
\hline
\end{tabular}

TENSTLE TEST

Polyvinyl Chloride

\begin{tabular}{|c|c|c|c|c|c|}
\hline $\begin{array}{l}\text { G1-G4 } \\
\text { G5-G9 } \\
\text { G9-G12 } \\
\text { G17-G20 }\end{array}$ & $\begin{array}{c}0 \\
35.6 \\
35.6 \\
35.6\end{array}$ & $\begin{array}{r}0 \\
49 \\
97 \\
164\end{array}$ & $\begin{array}{r}0 \\
105 \\
207 \\
350\end{array}$ & $\begin{array}{l}684 \\
553 \\
522 \\
533\end{array}$ & $\begin{array}{r}100 \\
81 \\
76 \\
78\end{array}$ \\
\hline $\begin{array}{l}\mathrm{G} 17-\mathrm{G} 20 \\
\mathrm{G} 25-\mathrm{G} 28 \\
\mathrm{G} 25-\mathrm{G} 28 \\
\mathrm{G} 29-\mathrm{G} 32\end{array}$ & $\begin{array}{l}35.6 \\
35.6 \\
35.6 \\
35.6\end{array}$ & $\begin{array}{l}218 \\
266 \\
338 \\
385\end{array}$ & $\begin{array}{l}464 \\
566 \\
720 \\
824\end{array}$ & $\begin{array}{l}541 \\
546 \\
543 \\
548\end{array}$ & $\begin{array}{l}79 \\
80 \\
80 \\
80\end{array}$ \\
\hline $\begin{array}{l}\text { G33-G36 } \\
\text { G33-G36 } \\
G 37-G 40\end{array}$ & $\begin{array}{l}35.6 \\
35.6 \\
35.6\end{array}$ & $\begin{array}{l}434 \\
505\end{array}$ & $\begin{array}{r}926 \\
1080\end{array}$ & $\begin{array}{l}544 \\
555 \\
503\end{array}$ & $\begin{array}{l}80 \\
80 \\
74\end{array}$ \\
\hline \multicolumn{6}{|c|}{ Non-plasticized Fluorothene } \\
\hline $\begin{array}{l}\text { Blank } \\
\mathrm{HI}-\mathrm{H} 4 \\
\mathrm{H} 5-\mathrm{H} \text { and up }\end{array}$ & $\begin{array}{c}0 \\
35.6 \\
35.6\end{array}$ & $\begin{array}{r}0 \\
49 \\
97\end{array}$ & $\begin{array}{r}0 \\
60 \\
118\end{array}$ & $\begin{array}{r}326 \\
53 \\
0\end{array}$ & $\begin{array}{r}100 \\
16 \\
0\end{array}$ \\
\hline
\end{tabular}

Plasticized Fluorothene

\begin{tabular}{lrrrrr} 
J1-J4 & 0 & 0 & 0 & 134 & 100 \\
J5-J8 & 35.6 & 72 & 153 & 22 & 16 \\
J9-J and up & 35.6 & 120 & 254 & 0 & 0 \\
\hline
\end{tabular}

SHEAR TEST

Polyvinyl Chloride

\begin{tabular}{|c|c|c|c|c|c|}
\hline Blank & 0 & 0 & 0 & 2004 & 100 \\
\hline M1-M4 & 20.6 & 52 & 65 & 2747 & 137 \\
\hline M5-M8 & 20.6 & 172 & 213 & 2616 & 130 \\
\hline M9-M12 & 20.6 & 220 & 273 & 2699 & 135 \\
\hline M13-M16 & 20.6 & 316 & 391 & 2676 & 134 \\
\hline M17-M20 & 20.6 & 365 & 452 & 2600 & 130 \\
\hline M21-M24 & 20.6 & 411 & 507 & 2521 & 126 \\
\hline M25-M28 & 20.6 & 480 & 594 & 2391 & 119 \\
\hline M29-M32 & 20.6 & 534 & 660 & 2243 & 112 \\
\hline M33-M36 & 20.6 & 582 & 720 & 2099 & 105 \\
\hline M37-M40 & 20.6 & 654 & 810 & 1926 & 96 \\
\hline & & & ized & & \\
\hline Blank & 0 & 0 & 0 & 1458 & 100 \\
\hline N1-N4 & 20.6 & 53 & 65 & 1565 & 107 \\
\hline N5-N8 & 20.6 & 172 & 212 & 478 & 33 \\
\hline N9-N12 & 20.6 & 220 & 271 & 439 & 30 \\
\hline N13-N16 & 20.6 & 316 & 388 & 367 & 25 \\
\hline N17-N2O & 20.6 & 365 & 449 & & \\
\hline N24 & 20.6 & 411 & 514 & 115 & 8 \\
\hline & & & ed F1 & & \\
\hline Q1-Q4 & 0 & 0 & 0 & 915 & \\
\hline Q5-Q8 & 20.6 & 72 & 89 & 1065 & \\
\hline Q9-Q12 & 20.6 & 120 & 147 & 1143 & 125 \\
\hline Q13-Q16 & 20.6 & 168 & 207 & 950 & 104 \\
\hline Q17-Q20 & 20.6 & 240 & 295 & 515 & \\
\hline Q21-Q24 & 20.6 & 288 & 354 & 314 & 34 \\
\hline Q25-Q28 & 20.6 & 306 & 376 & 229 & 25 \\
\hline
\end{tabular}

ORTNTNAL STRENGTH

lb. force/sq.in. 



\section{2

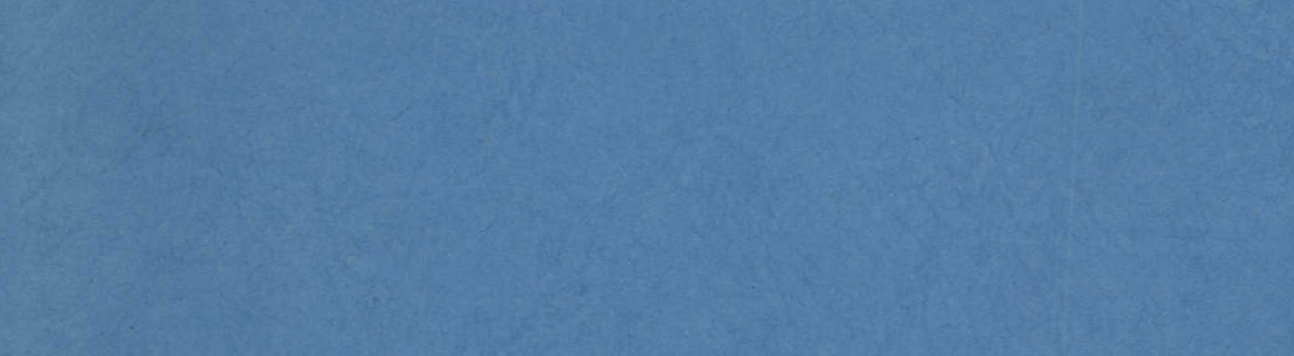
19.
(1)

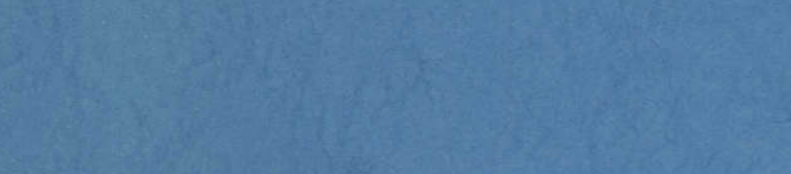

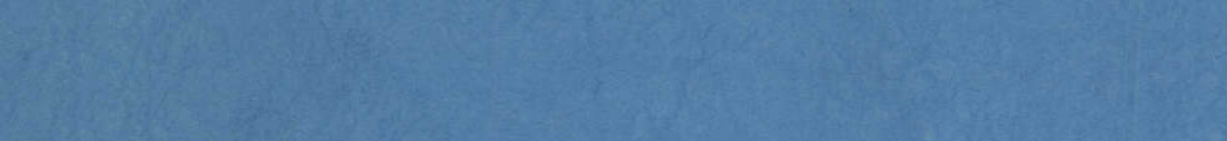

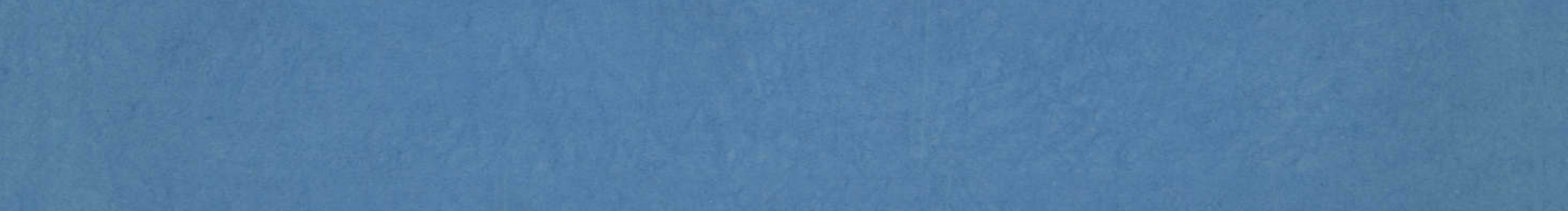
$309+2$ in
(3)

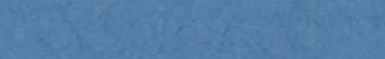

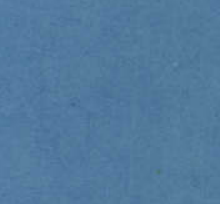

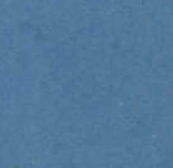
P.

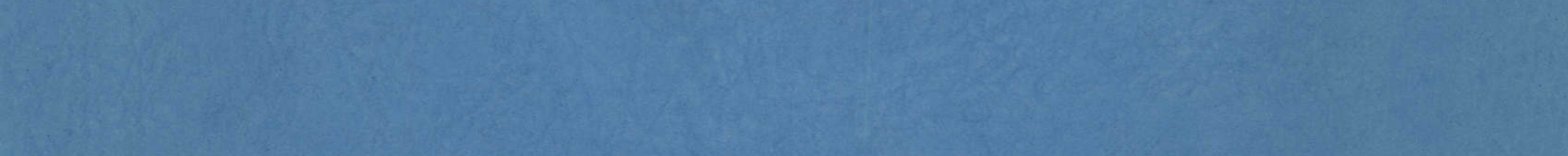

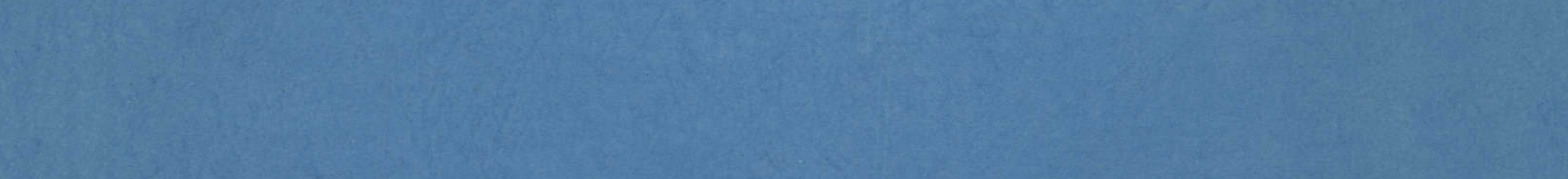
Lit.

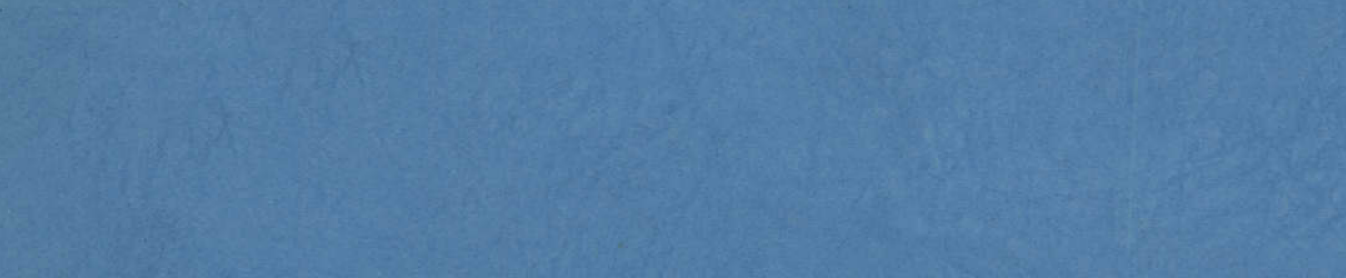
(1) 